\title{
Isothermal corrosion testing of frit furnace refractories
}

\author{
Fatih Balikoglu, Sedat Akkurt* \\ Mechanical Engineering Department, Izmir Institute of Technology, 35430 Izmir, Turkey \\ Received 12 December 2008; received in revised form 11 March 2009; accepted 12 June 2009 \\ Available online 7 July 2009
}

\begin{abstract}
In this paper, the corrosion behaviour of aluminosilicate type refractories in frit melts is studied in an isothermal corrosion test setup. A refractory brick of largely andalusite and sillimanite composition was compared to another refractory brick of mullite and sillimanite composition, both of which were made by different manufacturers for use in different frit furnaces. The industrial frit used for corrosion tests was a commercial product used in a wall tile glaze formulation. Corrosion tests conducted under isothermal conditions provide quantitative and reproducible data about the corrosion performance of refractories. In this study, tests were performed by partially immersing a $15 \mathrm{~mm} \times 15 \mathrm{~mm} \times 115 \mathrm{~mm}$ refractory specimen into a frit melt at temperatures between 1404 and $1504{ }^{\circ} \mathrm{C}$. The effects of temperature, duration of exposure and the refractory brick type were investigated using a statistically designed set of experiments. The ANOVA (analysis of variance) table indicated that temperature and test duration were the most important factor effects, as expected. Increasing both temperature and exposure duration led to an increased amount of corrosion as measured by the cross-sectional area loss of the corroded refractory specimen. Postmortem microstructural analysis was also done on the specimens, with extensive amount of $\mathrm{ZnO} \cdot \mathrm{Al}_{2} \mathrm{O}_{3}$ precipitation observed along the frit-refractory interface, where crystals of mullite and alumina were also found to precipitate. Increasing the amount of exposure time and temperature produced more $\mathrm{ZnO} \mathrm{Al}_{2} \mathrm{O}_{3}$ precipitation. As identified by SEM-EDS analysis, mullite crystals were in the needle-like morphology, while alumina crystals were generally cubic. Additional experiments were conducted by rotating the specimens in the melt at $50 \mathrm{rpm}$ of rotational speed. Due to the reduction of boundary layer thickness, more dissolution was observed from the rotated specimens. In all specimens, corrosion was more pronounced in the bond phase than through the large filler grains of mullite and andalusite.
\end{abstract}

(C) 2009 Elsevier Ltd and Techna Group S.r.l. All rights reserved.

Keywords: C. Corrosion; E. Refractories; Frit; Test

\section{Introduction}

Frit is a glassy material composed largely of silica, alumina, alkali and alkaline earths. It is an intermediate product that is used in making glaze, which is used to coat ceramic articles. The reason for making frit is to form a water insoluble and homogeneous material for preparing glaze formulations. Many ceramic tile manufacturers produce their own frit, so they have their own glaze formulations to allow independence from frit suppliers. Commercial frits can be produced in either continuous or rotary type furnace. Frit kilns of a continuous type are generally used for frit production, and are rectangular in construction, with raw materials fed in at one end and the frit melt discharged from the other end. The furnaces have

\footnotetext{
* Corresponding author. Tel.: +90 232750 6192; fax: +90 2327507890 .

E-mail addresses: fatihbalikoglu@iyte.edu.tr (F. Balikoglu), sedatakkurt@iyte.edu.tr (S. Akkurt).
}

refractory linings used in their floors, sidewalls, and discharge locations; which are under varying amounts of frit attack at operational temperatures [1]. Many producers suffer from premature failure of their refractories because of incorrect material choices or improper choice of operating conditions. However, ceramic producers concentrate more on the production parameters of tile or sanitary products, and generally lack the expertise to identify the correct type of refractories for their kilns. Hence, they become dependent on supplier's advice. It is known that large savings can be realised by extending furnace campaign life and delaying repairs as long as possible [2]. For this reason, the effects that are responsible for campaign duration must be clarified and investigated carefully to prevent premature shutdown in the frit furnaces. The long campaign duration for a frit melting furnace depends on many factors, including: properties of refractory bricks, their temperature and corrosion resistance in the melt and in the aggressive gaseous atmosphere saturated with volatile gases from batch components and fuel combustion products, service condition of 
Table 1

Composition of transparent frit and refractories samples used in corrosion testing. SEM-EDS was used for chemical analysis.

\begin{tabular}{|c|c|c|c|c|c|c|}
\hline & \multirow{2}{*}{$\begin{array}{l}\text { Composition of } \\
\text { frit (wt } \%)\end{array}$} & \multicolumn{3}{|c|}{ Composition of brick E (wt\%) } & \multicolumn{2}{|c|}{ Composition of brick $\mathrm{T}$ (wt\%) } \\
\hline & & Overall composition & Mullite grain & Sillimanite grain & Overall composition & Andalusite or sillimanite grain \\
\hline $\mathrm{Na}_{2} \mathrm{O}$ & 0.0 & 1.3 & 1.1 & 1.6 & 1.2 & 0.8 \\
\hline $\mathrm{K}_{2} \mathrm{O}$ & 6.1 & 0.3 & 0.2 & 0.5 & 1.0 & 0.4 \\
\hline $\mathrm{MgO}$ & 2.2 & 1.4 & 1.1 & 1.7 & 1.3 & 0.9 \\
\hline $\mathrm{CaO}$ & 8.4 & 0.6 & 0.2 & 1.2 & 1.0 & 0.5 \\
\hline $\mathrm{Al}_{2} \mathrm{O}_{3}$ & 9.3 & 58.8 & 63.1 & 52.8 & 55.0 & 56.9 \\
\hline $\mathrm{SiO}_{2}$ & 52.7 & 36.4 & 33.4 & 39.8 & 37.9 & 39.3 \\
\hline $\mathrm{Fe}_{2} \mathrm{O}_{3}$ & 0.0 & 1.2 & 0.9 & 2.4 & 2.6 & 1.3 \\
\hline $\mathrm{B}_{2} \mathrm{O}_{3}$ & 8.5 & 0.0 & 0.0 & 0.0 & 0.0 & 0.0 \\
\hline $\mathrm{ZnO}$ & 12.8 & 0.0 & 0.0 & 0.0 & 0.0 & 0.0 \\
\hline
\end{tabular}

brickwork elements, and frit melting parameters (temperature level, chemistry of frit and type of fuel) [3]. One of the most important properties of refractory bricks used to line frit melting furnaces is their corrosion resistance to aggressive frit melt [4].

Corrosion of refractory bricks happens when these materials are subjected to high temperatures in contact with corrosive substances. Corrosion is a complex phenomenon, depending on the chemical composition of bricks and frit, furnace temperature, and design parameters of a furnace (refractory position in furnace). Corrosion occurs via different types of mechanisms for each refractory material. Corrosion of refractories involves dissolution, penetration, and reaction processes. In most instances, these mechanisms occur in combination [5].

The choice of bricks used as lining in furnaces for melting frit glaze can be based on experiments determining corrosion resistance of refractories in frit melts [4]. Corrosion properties of refractories measured under non-isothermal conditions, however, cannot provide an accurate estimate of the amount of corrosion that would occur in a commercial environment. This is a result of the presence of a freeze plane within the brick that complicates the corrosive processes [3]. It is extremely difficult to reproduce test conditions and to locate the freeze plane in exactly the same location during repeated tests. However, in an isothermal test, where every point of the refractory specimen and the corrosive medium (frit) are at the same temperature, the corrosion performance is reliable and reproducible [6].

In this study, corrosion behaviours of aluminosilicate refractories in contact with frit melts are investigated to determine their corrosion mechanisms and to measure their performance. Aluminosilicate refractories are generally employed in frit kilns due to their low cost, however, their service performance is generally unsatisfactory [7]. Extensive corrosion of these refractories limits their service lives. Andalusite, silimanite and mullite based fired bricks are commonly used in such furnaces. These bricks were studied for their corrosion behaviour in contact with steel slag, but in the literature, no study was found on their corrosion resistance in contact with molten frit at a fixed temperature (with no thermal gradient during the test $[4,8]$ ). A corrosion testing method and a test protocol for frit kiln refractories were produced by mimicking the conditions in the frit kiln application. Some previous experimental setups used in corrosion testing were investigated to guide this study [9-14]. Dip/dip and rotation test (finger, rotating pencil test) was thought to be suitable for determining corrosion behaviours under both static and dynamic conditions that involved stagnant and flowing molten frit attack on a refractory sample. Finally, postmortem microstructural analysis of tested brick specimens was investigated by SEM, optical microscope and XRD methods to determine the factors related to refractory corrosion.

\section{Materials}

Two commercially available refractory bricks, mullitic $\left(3 \mathrm{Al}_{2} \mathrm{O}_{3} \cdot 2 \mathrm{SiO}_{2}\right)$ brick (coded $\left.\mathrm{E}\right)$ and andalusite $\left(\mathrm{Al}_{2} \mathrm{O}_{3} \cdot \mathrm{SiO}_{2}\right)$ brick (coded $\mathrm{T}$ ) were tested in this project to understand their corrosion behaviour in contact with a molten frit at 1404-1504 ${ }^{\circ} \mathrm{C}$. Both bricks also contained some sillimanite $\left(\mathrm{Al}_{2} \mathrm{O}_{3} \cdot \mathrm{SiO}_{2}\right)$. Microstructural analyses by SEM and OM (optical microscope) revealed two populations of grain sizes, large grains (about $1 \mathrm{~mm}$ in diameter) surrounded by a matrix of fine grains $(1-50 \mu \mathrm{m})$ that provided bonding after firing of the brick. Both bricks contained some sillimanite, while brick T also contained large crystals of andalusite and brick E had large mullite grains embedded in fine particles of the same composition (Table 1 and Figs. 1 and 2). XRD analysis of refractory bricks confirmed that $\mathrm{T}$ brick consisted of andalusite

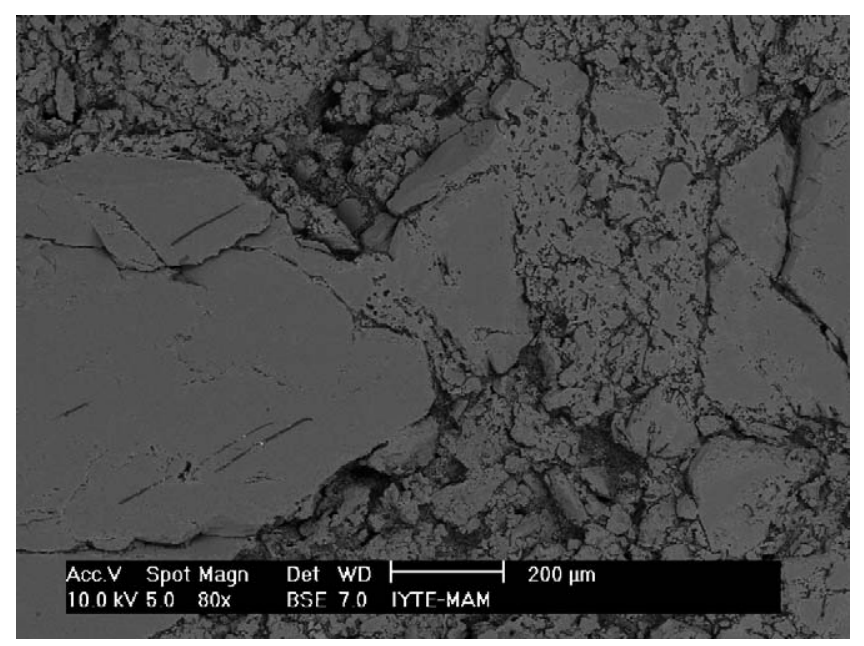

Fig. 1. SEM micrograph of polished cross-section of refractory brick sample T. 


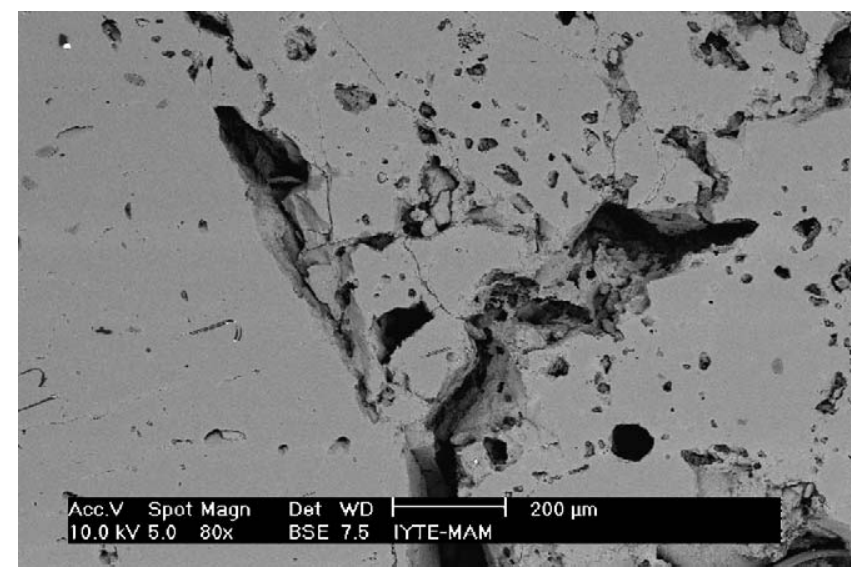

Fig. 2. SEM micrograph of polished cross-section of refractory brick sample E.

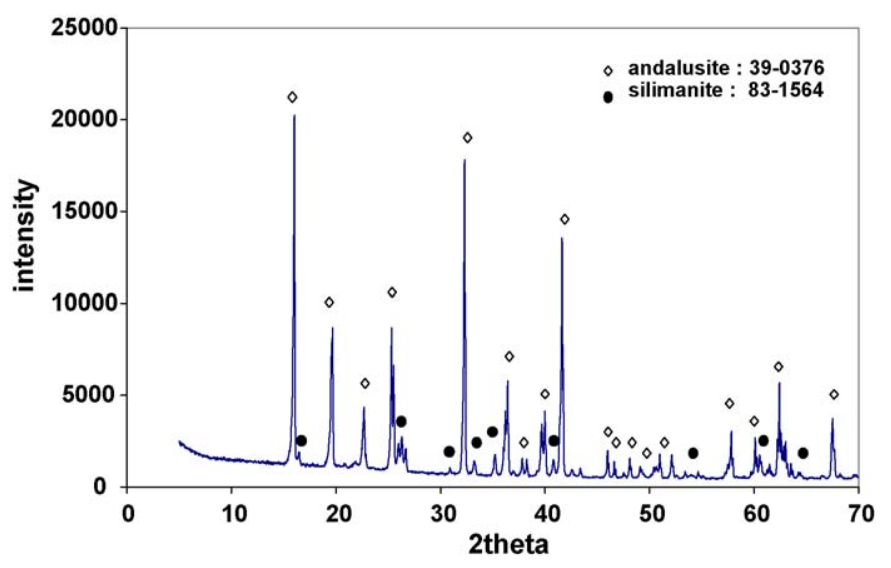

Fig. 3. XRD pattern of original T refractory brick.

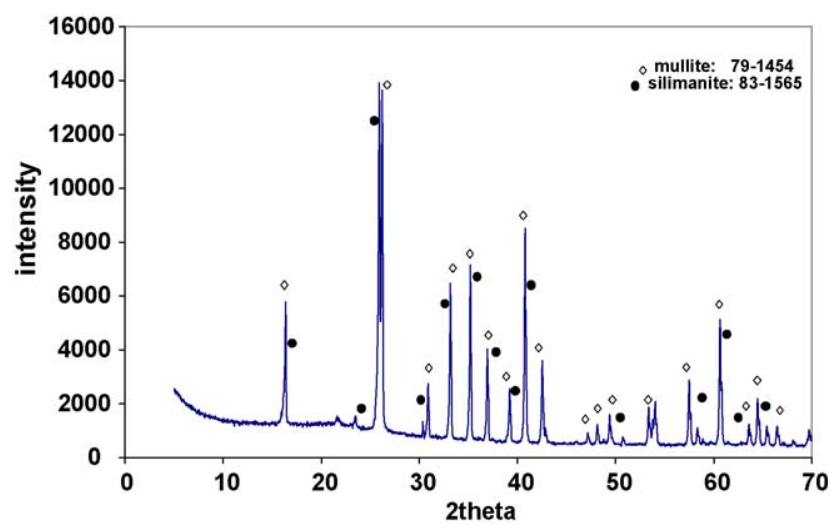

Fig. 4. XRD pattern of original E refractory brick.

and sillimanite, while E brick was composed of mullite and sillimanite (Figs. 3 and 4). The chemical composition of both refractory samples as measured by SEM-EDS is given in Table 1 . The $\mathrm{T}$ and $\mathrm{E}$ refractory specimens are both classified as aluminosilicate refractories, with $\mathrm{T}$ brick slightly richer in alumina. Selected measured physical properties of the bricks are given in Table 2. A transparent frit with high zinc and aluminum supplied by a local ceramic manufacturer was used for corrosion tests. X-ray diffraction analysis of the transparent
Table 2

Some physical properties of brick samples.

\begin{tabular}{lcc}
\hline Property & Brick T & Brick E \\
\hline Apparent porosity $(\%)$ & 13.0 & 12.3 \\
Bulk density $\left(\mathrm{g} / \mathrm{cm}^{3}\right)$ & 2.6 & 2.6 \\
Compressive strength $(\mathrm{MPa})$ & 11 & 35 \\
\hline
\end{tabular}

frit is given in Fig. 5. As can be seen from the XRD pattern, the frit sample was entirely amorphous. Chemical composition of the frit as measured by XRF is given in Table 1.

\section{Experimental procedure}

In this study, the corrosion resistances of bricks in contact with molten frit were investigated in both static and dynamic corrosion test conditions using a stagnant and a turbulent molten frit, respectively. The corrosion resistance of refractories under isothermal conditions was measured in a vertical tube furnace using a bath of frit melt as the corroding medium that was contained in a high alumina crucible. Refractory samples $(15 \mathrm{~mm} \times 15 \mathrm{~mm} \times 115 \mathrm{~mm})$ were half-immersed from the top for prescribed amounts of time and at the test temperature. Temperature, time and type of refractory were varied in all experiments to observe their effects on corrosion of the refractory samples. The testing geometry used was similar to ASTM C-621, and can be found as dip/dip and rotation or finger test in the literature $[6,9,10]$.

\subsection{Experimental setup}

The experimental setup consisted of a vertical tube furnace (max temperature rating $1750{ }^{\circ} \mathrm{C}$ ) heated by $\mathrm{MoSi}_{2}$ heating elements and a motor assembly that allowed refractory specimen to be lowered, raised and rotated at $50 \mathrm{rpm}$. An alumina protection tube ( $1 \mathrm{~m}$ long and $100 \mathrm{~mm}$ diameter) was mounted vertically in the test furnace. High alumina crucibles were produced by slip casting, then fired at $1550{ }^{\circ} \mathrm{C}$ to contain the molten frit in the furnace. The high alumina crucible containing the molten frit was inside a safety crucible, which prevented any spillage of liquid frit to the inner wall of the

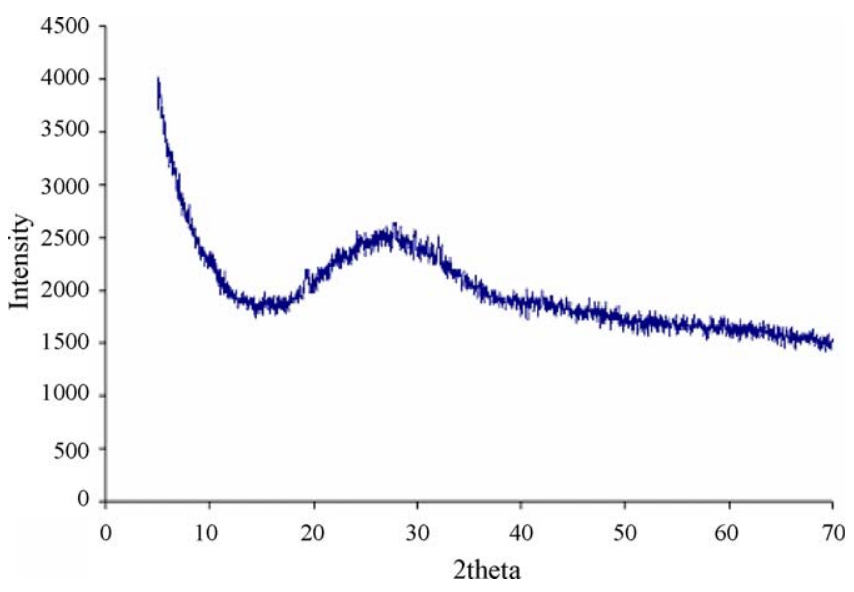

Fig. 5. XRD pattern of the transparent frit used in testing. 


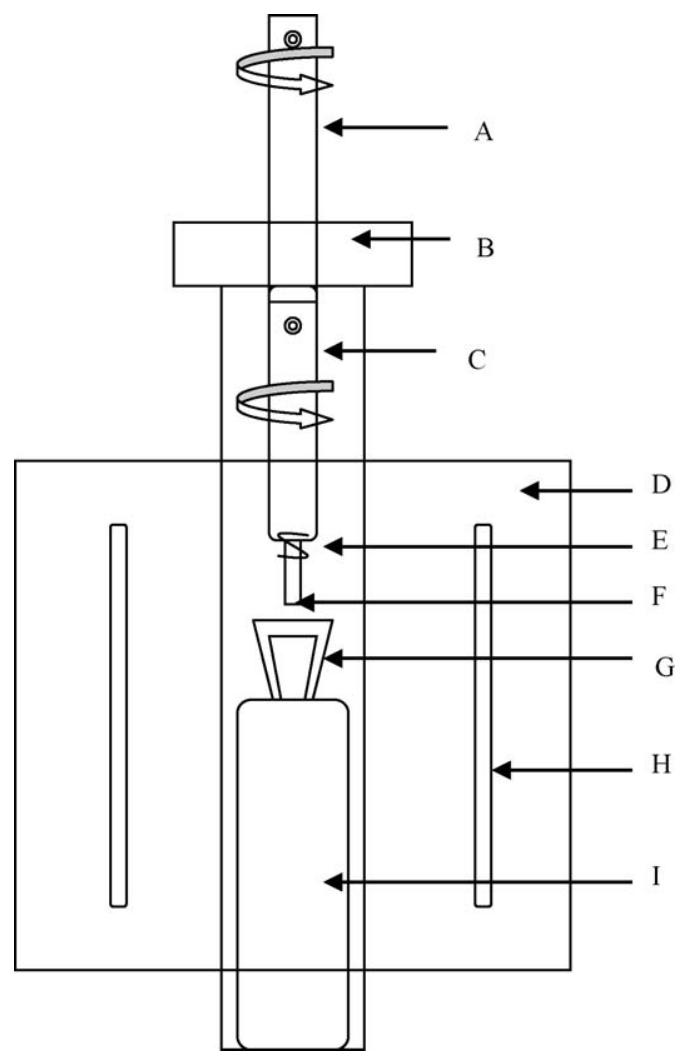

Fig. 6. A schematic of the experimental setup used for corrosion testing. A: steel shaft, B: upper-end cap, C: alumina tubing, D: vertical tube furnace, E: platinium wire, F: refractory sample, G: crucibles, $\mathrm{H}$ : heating elements of the furnace, I: kiln furniture.

alumina protection tube. The upper end-cap on the top of the $100 \mathrm{~mm}$ diameter protection tube was also produced in-house from a castable refractory mixture. A cylindrical block $(80 \mathrm{~mm}$ diameter and $500 \mathrm{~mm}$ long) was made from the same castable mixture as that used for making the upper end-cap, and was used as kiln furniture to support the crucible in the hot region of the furnace during the corrosion test. Square refractory specimens $(15 \mathrm{~mm} \times 15 \mathrm{~mm} \times 115 \mathrm{~mm})$ were cut from $\mathrm{T}$ and $\mathrm{E}$ commercially manufactured bricks. These samples were attached to an alumina tubing (diameter $=20 \mathrm{~mm}$ and $l=250 \mathrm{~mm})$ with a platinium wire $(0.5 \mathrm{~mm}$ diameter $)$ and connected by a steel shaft (15 $\mathrm{mm}$ diameter) to a motor for rotating test samples at $50 \mathrm{rpm}$. The schematic of the experimental setup is shown in Fig. 6.

\subsection{Experimental plan}

Static corrosion test experiments were planned using a statistical experiment design $[9,15,16]$, which enables one to obtain a maximum possible amount of information from a limited number of experimental runs. Because of the difficulty of experimentation in high temperature research, the statistical design is essential. The investigation started with a series of eight experiments designed according to the $2^{3}$ full factorial experiment design for static corrosion tests. The aim was to identify the most important factors affecting refractory corrosion.
Table 3

Parameters of static corrosion tests.

\begin{tabular}{llr}
\hline Type of refractory & Temperature $\left({ }^{\circ} \mathrm{C}\right)$ & Time $(\mathrm{h})$ \\
\hline $\mathrm{T}$ & 1404 & 4 \\
$\mathrm{~T}$ & 1404 & 24 \\
$\mathrm{~T}$ & 1504 & 4 \\
$\mathrm{~T}$ & 1504 & 24 \\
$\mathrm{E}$ & 1404 & 4 \\
$\mathrm{E}$ & 1404 & 24 \\
$\mathrm{E}$ & 1504 & 4 \\
$\mathrm{E}$ & 1504 & 24 \\
\hline
\end{tabular}

\subsubsection{Full factorial experiments}

The factor effects chosen for the experimental design were duration of molten frit exposure, temperature, and type of refractory (Table 3). The response variable was percent area loss due to corrosion. Time, temperature, and type of refractory were the only variables changed in all experiments in this study. It is important to remember that in commercial service, refractory bricks used in the lining of the frit furnace are exposed to other harsh effects; including thermal shock, and flow of the molten and alkali vapour, causing an increase in the corrosion of those materials during service $[3,10]$.

\subsection{Experimental conditions}

The corrosion test apparatus was able to accommodate continuous operation of the simulated frit kiln environment at high temperatures. A typical run began by loading frit into the reaction crucible and heating it at $10{ }^{\circ} \mathrm{C} / \mathrm{min}$ to the test temperature. Refractory specimens were rotated in the molten frit using an electric motor located on the test furnace frame to simulate flowing frit attack in a dynamic corrosion test. The setup could also be run under controlled atmosphere, but this was not used in this study as both end caps were left open to the air. After reaching test temperature, the refractory specimens were lowered into the molten frit and held there half-immersed for $4-24 \mathrm{~h}$ of static corrosion tests at 1404 or $1504{ }^{\circ} \mathrm{C}$, as measured by a thermocouple inserted into the alumina protection tube (Table 3). Dynamic corrosion tests were carried out by half immersing refractory samples in the molten frit (as done in the static tests) and rotating at $50 \mathrm{rpm}$ in the frit melt from 10 to $60 \mathrm{~min}$ at 1418 or $1456{ }^{\circ} \mathrm{C}$ (Table 4).

\section{Percent wear measurements}

Refractory specimens were photographed after the run, and the percent area loss values graded by visual inspection to judge

Table 4

Working conditions of dynamic corrosion tests.

\begin{tabular}{lll}
\hline Type of refractory & Temperature $\left({ }^{\circ} \mathrm{C}\right)$ & Time $(\mathrm{min})$ \\
\hline $\mathrm{T}$ & 1418 & 10 \\
$\mathrm{~T}$ & 1418 & 60 \\
$\mathrm{~T}$ & 1456 & 10 \\
$\mathrm{~T}$ & 1456 & 60 \\
$\mathrm{E}$ & 1418 & 10 \\
$\mathrm{E}$ & 1456 & 60 \\
\hline
\end{tabular}


whether such predictions correlated with measured values of cross-sectional changes. Corroded refractory specimens were sliced longitudinally at the midsection using a low-speed diamond saw, then were polished and photographed. These photographs were used to calculate the percent area loss in the cross section. Large printouts of the photographs of the corroded samples on paper were cut out and weighed to measure the corroded fraction per total immersed cross sectional area. In this way, corrosion test results were obtained as numerical data to analyze statistically.

\section{Results of corrosion tests and discussion}

\subsection{Static corrosion test results}

Refractory specimens were immersed about one quarter of the way into the molten frit at temperatures between 1404 and $1504{ }^{\circ} \mathrm{C}$ during $4-24 \mathrm{~h}$ of static corrosion tests. As seen in Figs. 7 and 8, refractory specimens were corroded after static

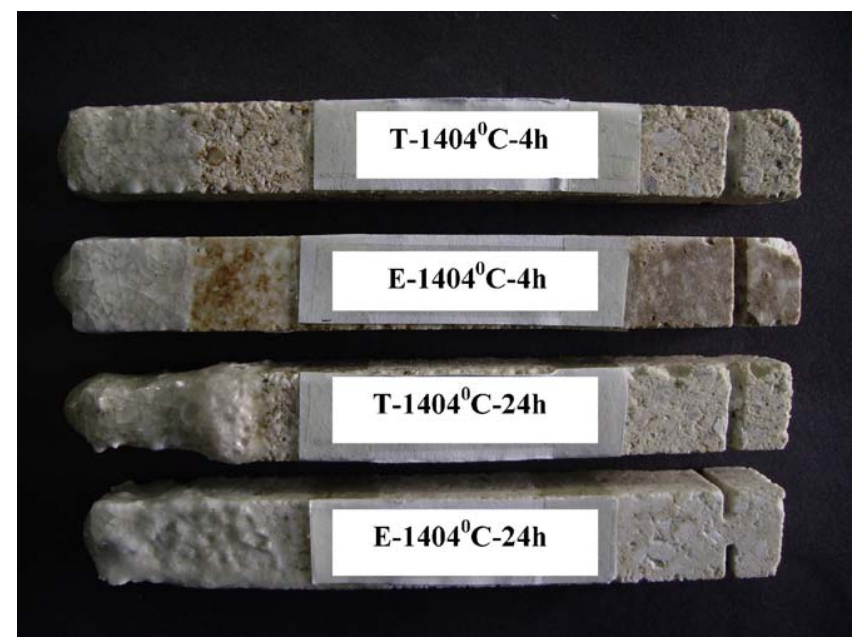

Fig. 7. A photograph of the corroded refractory specimens tested at $1404{ }^{\circ} \mathrm{C}$ for static corrosion tests (T-1404 ${ }^{\circ} \mathrm{C}-4 \mathrm{~h}$ : T brick was tested at $1404{ }^{\circ} \mathrm{C}$ for $4 \mathrm{~h}$ ).

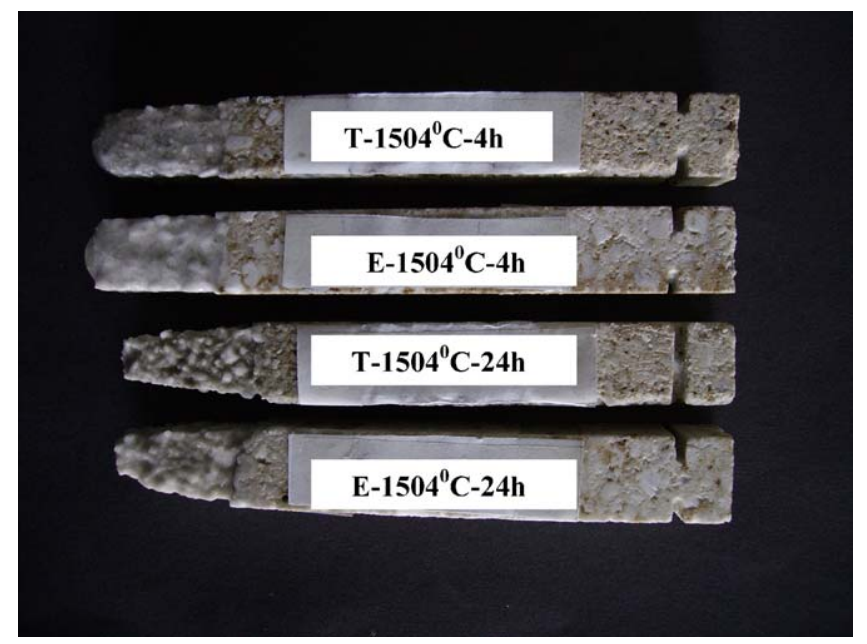

Fig. 8. A photograph of the corroded refractory specimens tested at $1504{ }^{\circ} \mathrm{C}$ for static corrosion tests.
Table 5

Percent cross-sectional area losses of the corroded refractory specimens after static corrosion tests.

\begin{tabular}{lcc}
\hline Refractory specimens & $\begin{array}{l}\text { \% Area loss by } \\
\text { observation before } \\
\text { cutting }\end{array}$ & $\begin{array}{l}\text { \% Cross-sectional } \\
\text { area loss as } \\
\text { measured }\end{array}$ \\
\hline $\mathrm{T}-1404{ }^{\circ} \mathrm{C}-4 \mathrm{~h}$ & 0 & 0 \\
$\mathrm{E}-1404^{\circ} \mathrm{C}-4 \mathrm{~h}$ & 0 & 0 \\
$\mathrm{~T}-1404{ }^{\circ} \mathrm{C}-24 \mathrm{~h}$ & 25 & 24 \\
$\mathrm{E}-1404{ }^{\circ} \mathrm{C}-24 \mathrm{~h}$ & 15 & 18 \\
$\mathrm{~T}-1504{ }^{\circ} \mathrm{C}-4 \mathrm{~h}$ & 20 & 19 \\
$\mathrm{E}-1504{ }^{\circ} \mathrm{C} 4 \mathrm{~h}$ & 10 & 15 \\
$\mathrm{~T}-1504{ }^{\circ} \mathrm{C} 24 \mathrm{~h}$ & 40 & 36 \\
$\mathrm{E}-1504{ }^{\circ} \mathrm{C} 24 \mathrm{~h}$ & 35 & 30
\end{tabular}

Table 6

ANOVA table of the corrosion data obtained from static corrosion test results.

\begin{tabular}{llrrrl}
\hline Source & d.f. & \multicolumn{1}{l}{ SS } & MS & \multicolumn{1}{l}{$F$} & $p$ \\
\hline A: temperature & 1 & 420.5 & 420.5 & 210.3 & 0.04 \\
B: time & 1 & 684.5 & 684.5 & 342.3 & 0.03 \\
C: type of refractory & 1 & 32.0 & 32.0 & 16.0 & 0.16 \\
AB & 1 & 12.5 & 12.5 & 6.25 & 0.24 \\
AC & 1 & 2.0 & 2.0 & 1.0 & 0.50 \\
BC & 1 & 8.0 & 8.0 & 4.0 & 0.29 \\
Error & 1 & 2.0 & 2.0 & & \\
Total & 7 & 1161.5 & & & \\
\hline
\end{tabular}

testing, with the amount of corrosion significantly increasing at higher temperatures and immersion times. The percent area losses of the corroded refractory specimens after static corrosion tests are given in Table 5 .

Table 5 confirmed that the corrosive loss of material increased with increasing test temperature and duration, regardless of the technique used to measure area loss. On the basis of the data in Table 5, E bricks were about 20-30\% more resistant to corrosive frit melt when compared to $\mathrm{T}$ bricks after static corrosion tests under the same test conditions.

The analysis of variance (ANOVA) table obtained from data is given in Table 6. The factors are coded as follows: A: temperature, B: time and C: type of refractory. Percent wear (area loss) numbers are interchangeably used, with the term "corrosion" based on the assumption that erosion was not a big factor in this part of the study which involves static tests. Erosion is definitely not completely ruled out, but the term corrosion was used.

In ANOVA tables, a factor effect is more significant as its $p$ value gets smaller. A $p$-value of, for example, 0.05 means that the experimenter has $95 \%$ confidence that the parameter is significant. As can be seen in the ANOVA table (Table 6), the wear was impacted by the test temperature (A) and exposure duration (B) of the refractory to the frit melt; with the type of refractory having a much lower influence. There was no significant interaction term between the factor effects. The $R^{2}$ value, which is an indication of the quality of the fit of the model, was 0.98 . This was very encouraging because the 


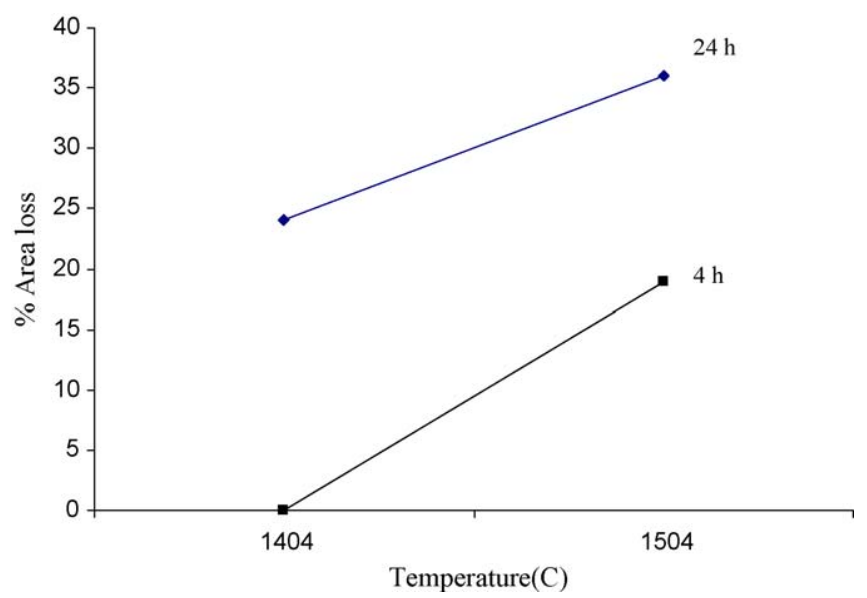

Fig. 9. The effects of temperature and time on corrosion of $\mathrm{T}$ brick in static corrosion tests.

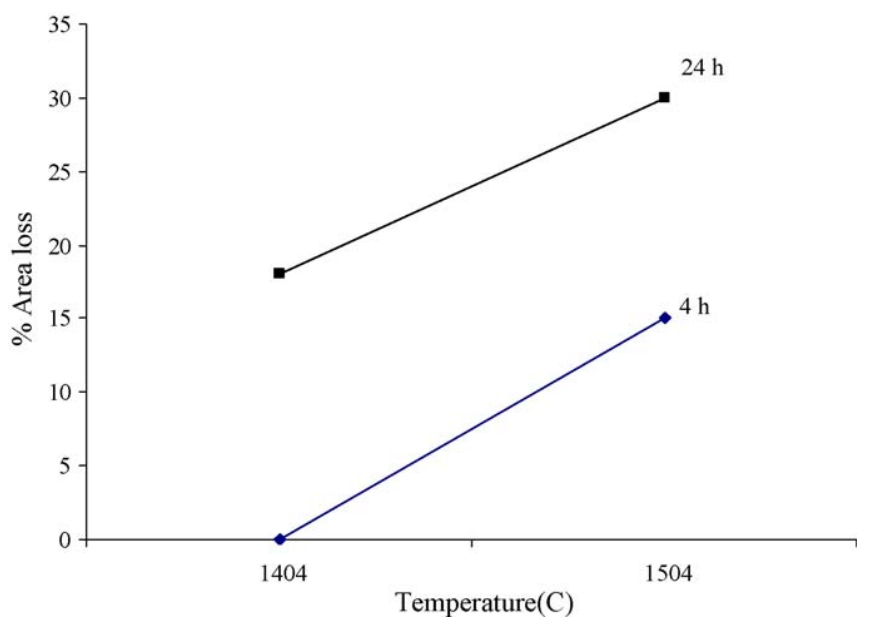

Fig. 10. The effects of temperature and time on corrosion of E brick in static corrosion tests.

reliability of the test method used was important. Figs. 9 and 10 show a plot of the effect of temperature on corrosion at varying levels of exposure durations. As can be seen from the figures, not much interaction was observed between the factor effects for both bricks.

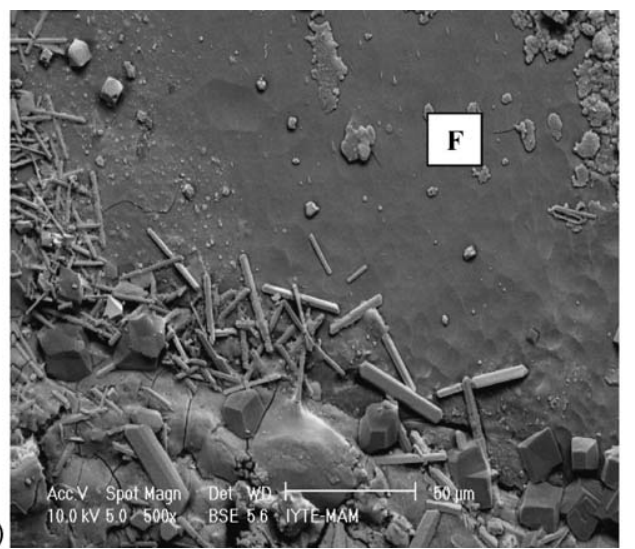

(b)

Postmortem microstructural analyses of the corroded refractory specimens were also done in their cross-sectional zones after corrosion tests. In this way, phase changes along the frit-refractory interface and in the cooled frit melt were evaluated to determine the corrosion mechanism in the static and dynamic conditions. It is known that no matter which corrosive agent was used, all the corrosion profiles observed in the corroded refractory bricks included four zones, each with different textures. Those zones were as follows: remnant frit, precipitation zone, penetrated zone and unaffected zone [8]. These four zones were observed in all samples after corrosion tests.

SEM and EDX analysis of the corroded refractory specimens after corrosion testing showed the dissolution of aluminum from the refractory grains into the frit melt. The aluminum dissolution enriched the frit with respect to aluminum ions, which on cooling precipitated out of the melt in the form of idiomorphic grains. SEM images of the $\mathrm{T}$ refractory-frit interface after exposure at $1404{ }^{\circ} \mathrm{C}$ for $4 \mathrm{~h}$ of the refractory sample to frit are shown in Fig. 11. All corrosion experiments were conducted in open air. Corundum $\left(\mathrm{Al}_{2} \mathrm{O}_{3}\right)$ with cuboidal shapes was observed along $\mathrm{T}$ refractory-frit interface. These crystals had the same cuboidal habit observed by Xiao and Mitchell [17]. Mullite precipitates with needle-like shapes were also detected in the $\mathrm{T}$ samples (Fig. 11), with corundum crystals clustered along $T$ refractory-frit interface. It is of interest to note that mullite crystals with a needle-like shape had been reported by Iqbal and Lee [18].

SEM image of $\mathrm{T}$ refractory specimens tested at $1504{ }^{\circ} \mathrm{C}$ for $4 \mathrm{~h}$ is given in Fig. 12. It is of interest to note that mullite crystals with needle-like shape were embedded within the cooled frit and $\mathrm{ZnO} \cdot \mathrm{Al}_{2} \mathrm{O}_{3}$ precipitates were clustered on the cooled frit surface in Fig. 12. It is suspected that $\mathrm{ZnO} \cdot \mathrm{Al}_{2} \mathrm{O}_{3}$ crystals that formed had the $\mathrm{Al}_{2} \mathrm{O}_{3}$ source as the refractory while the frit supplied zinc. Precipitation of $\mathrm{ZnO} \cdot \mathrm{Al}_{2} \mathrm{O}_{3}$ was also observed by Senoz and Akkurt in their study on frit melt in contact with a 98\% alumina crucible [19]. SEM and EDS results of the corroded refractory specimens after static corrosion tests indicated that corundum with different shapes, mullite and $\mathrm{ZnO} \cdot \mathrm{Al}_{2} \mathrm{O}_{3}$ crystals was identified along the frit-

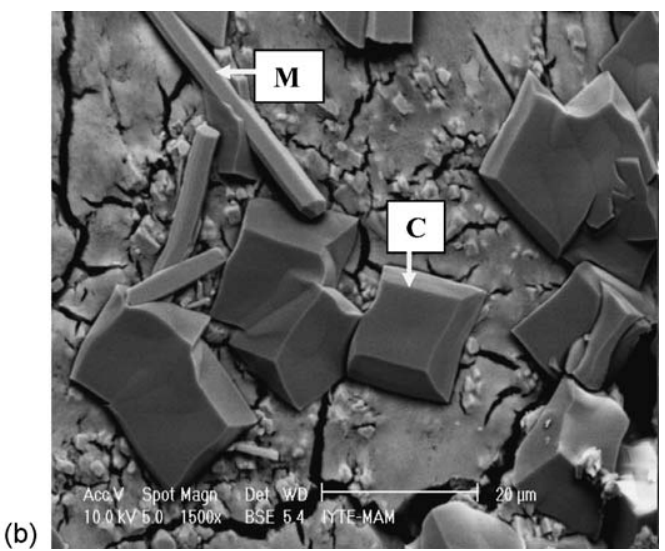

Fig. 11. SEM images of cross-sectional area of T refractory specimens tested at $1404{ }^{\circ} \mathrm{C}$ for $4 \mathrm{~h}$ in static corrosion tests. F: cooled frit zone, M: mullite, C: corundum. (a) $\mathrm{T}$ refractory-frit interface and (b) corundum and mullite crystals precipitated at $\mathrm{T}$ refractory-frit interface. 


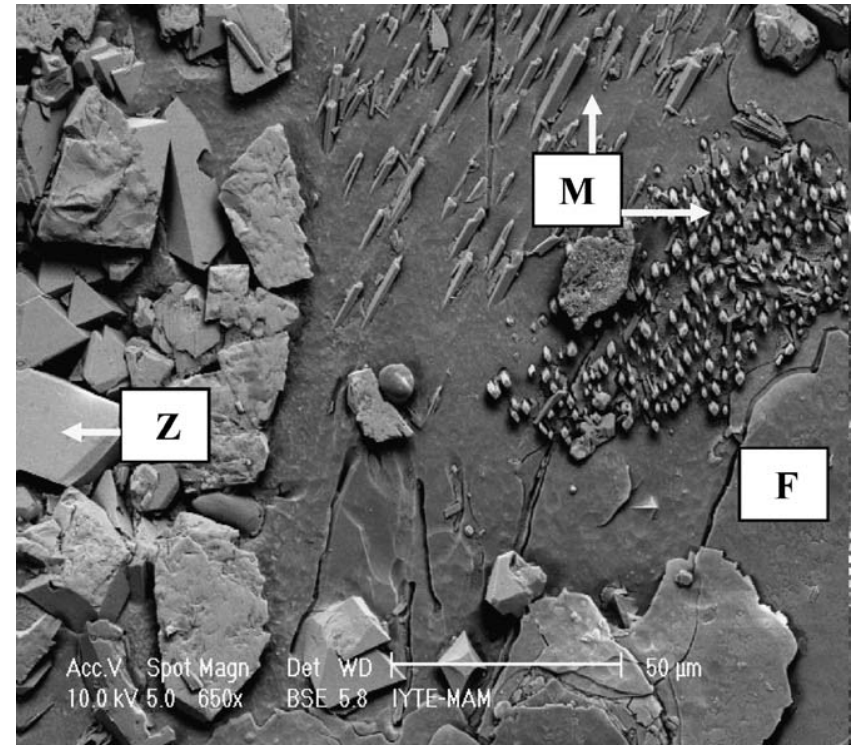

Fig. 12. SEM image of cross-sectional area of $\mathrm{T}$ refractory specimens tested at $1504{ }^{\circ} \mathrm{C}$ for 4 h. M: mullite with needle-like shape crystal, $\mathrm{Z}$ : $\mathrm{ZnO} \cdot \mathrm{Al}_{2} \mathrm{O}_{3}, \mathrm{~F}$ : cooled frit zone.

Table 7

Percent cross-sectional area losses of the corroded refractory specimens after dynamic corrosion tests.

\begin{tabular}{lll}
\hline Refractory specimens & $\begin{array}{l}\text { \% Area loss by } \\
\text { observation before } \\
\text { cutting }\end{array}$ & $\begin{array}{l}\% \text { Cross-sectional area } \\
\text { loss as measured }\end{array}$ \\
\hline
\end{tabular}

$\mathrm{T}-1418^{\circ} \mathrm{C}-10 \mathrm{~min}$

$\mathrm{T}-1456{ }^{\circ} \mathrm{C}-10 \mathrm{~min}$

$\mathrm{T}-1418{ }^{\circ} \mathrm{C}-60 \mathrm{~min}$

$\mathrm{T}-1456{ }^{\circ} \mathrm{C}-60 \mathrm{~min}$

$\mathrm{E}-1418^{\circ} \mathrm{C}-10 \mathrm{~min}$

E- $1456{ }^{\circ} \mathrm{C}-60 \mathrm{~min}$

\begin{tabular}{rr}
0 & 0 \\
2 & 4 \\
5 & 6 \\
10 & 13 \\
0 & 0 \\
5 & 7 \\
\hline
\end{tabular}

refractory interface and in the cooled frit. $\mathrm{ZnAl}_{2} \mathrm{O}_{4}$ spinel crystals increased with increasing immersion time, but decreased with increasing temperature by forming a discontinuous band at the frit-refractory interface. The loss of $\mathrm{ZnO}$ by evaporation may have caused this observation at higher temperature.

\subsection{Dynamic corrosion test results}

In dynamic corrosion tests, refractory specimens were rotated in molten frit at $50 \mathrm{rpm}$ at temperatures between 1418 and $1456{ }^{\circ} \mathrm{C}$ for $10-60 \mathrm{~min}$. As can be seen in Fig. 13, increasing test temperature and duration resulted in a higher amount of refractory corrosion after dynamic corrosion tests. A similar time/temperature trend was also observed in the static corrosion tests. The percent area loss values for refractory samples were calculated in the same way as in static corrosion tests (Table 7). Table 7 shows that the E brick materials were more resistant to molten frit than the $\mathrm{T}$ brick in dynamic corrosion tests. This similar trend was observed in the static corrosion tests. Furthermore, accelerated dissolution was

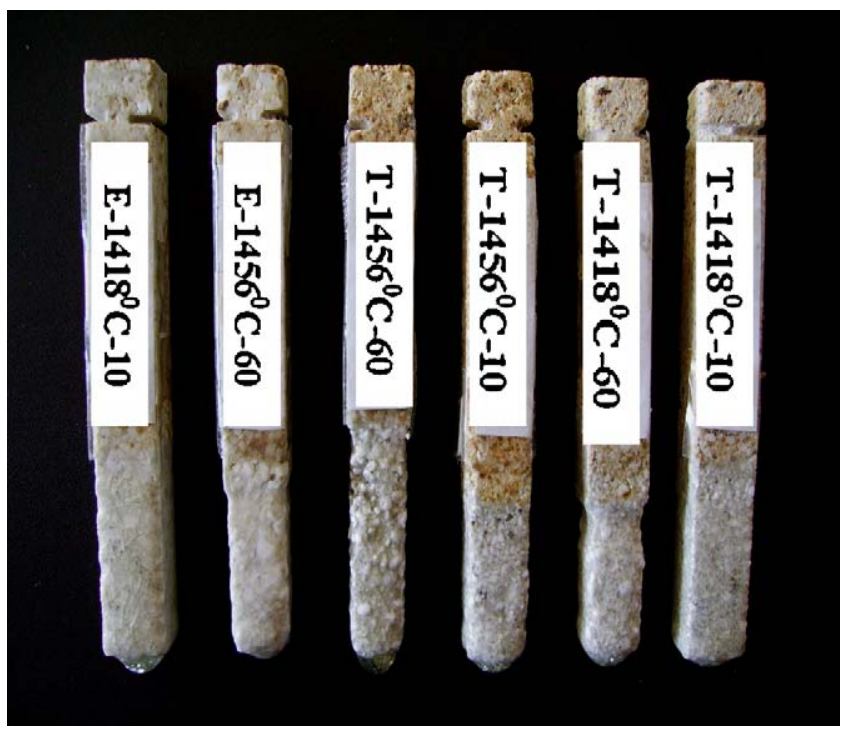

Fig. 13. A photograph of the corroded refractory bricks after dynamic corrosion tests. The following code was used indicate sample exposure conditions: E$1418{ }^{\circ} \mathrm{C}-10$ : E refractory specimen was tested at $1418^{\circ} \mathrm{C}$ during $10 \mathrm{~min}$.

observed after dynamic corrosion testing because of reduction of boundary layer thickness.

Postmortem microstructural analyses of the corroded refractory specimens were also carried out after dynamic corrosion testing. SEM images at two magnifications of the $\mathrm{T}$ refractory specimen tested at $1456{ }^{\circ} \mathrm{C}$ for $60 \mathrm{~min}$ are given in Figs. 14 and 15. The precipitation zone (marked in circle), remnant frit (the cooled frit) and unaffected zone (refractory grain) are indicated in Fig. 14. As shown in Fig. 15, small white crystals as corrosion products along the frit-refractory interface were identified as $\mathrm{ZnO} \cdot \mathrm{Al}_{2} \mathrm{O}_{3}$ crystals. Furthermore, mullite crystals were needle-like in shape, and corundum crystals

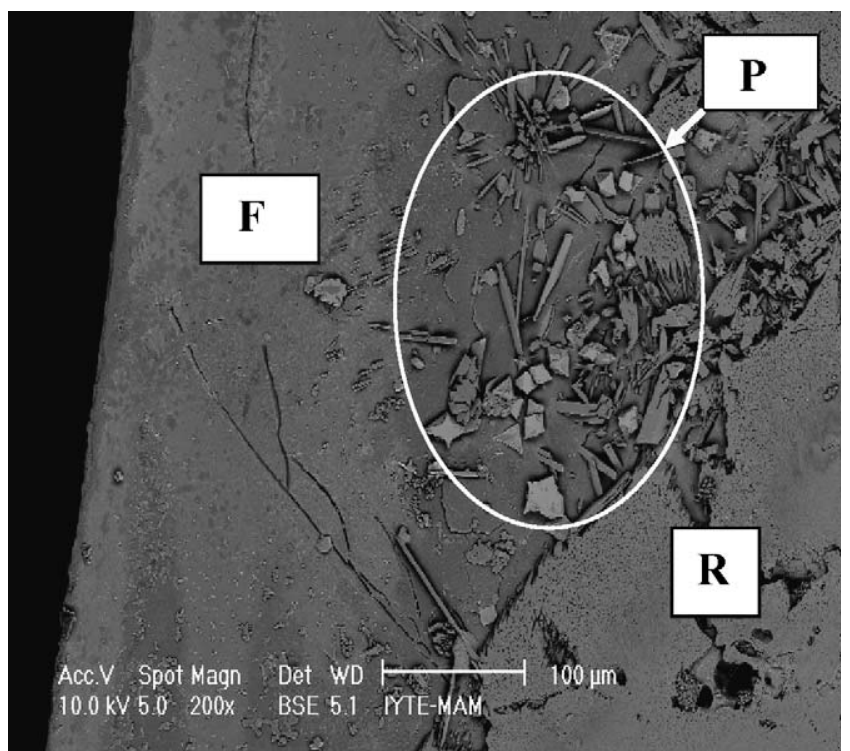

Fig. 14. SEM image of T refractory specimens tested at $1456{ }^{\circ} \mathrm{C}$ for $60 \mathrm{~min}$ in the dynamic corrosion test. R: refractory grain (unaffected zone), F: cooled frit (remnant frit), P: precipitation zone. 


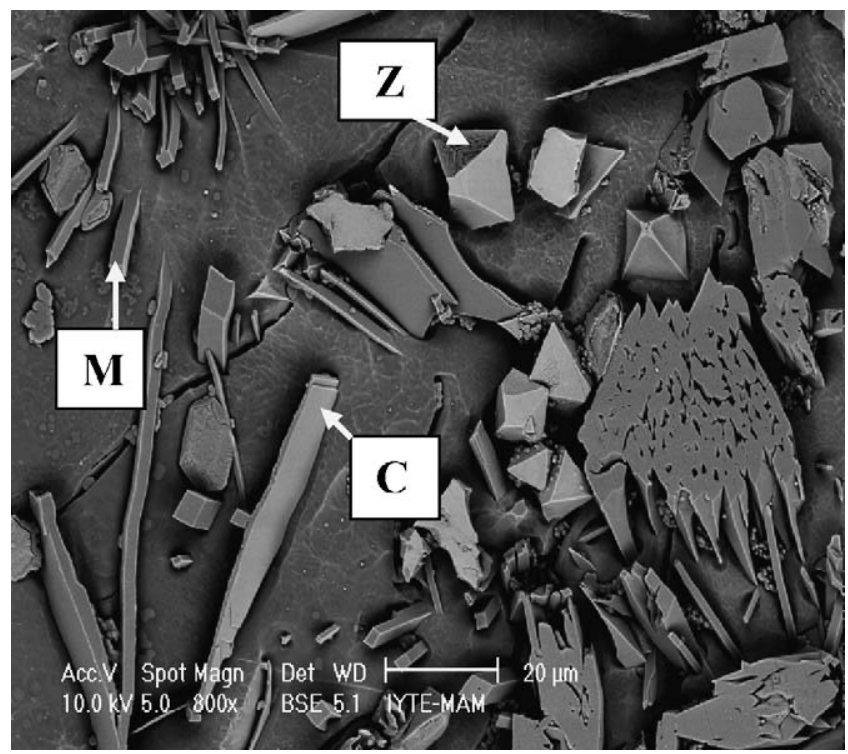

Fig. 15. SEM image of precipitation zone at $\mathrm{T}$ refractory specimens tested at $1456{ }^{\circ} \mathrm{C}$ for $60 \mathrm{~min}$ in the dynamic corrosion test. M: mullite, $\mathrm{C}$ : corundum, $\mathrm{Z}$ : $\mathrm{ZnO} \cdot \mathrm{Al}_{2} \mathrm{O}_{3}$.

formed as plate like crystals partially embedded within the cooled frit in Fig. 15.

It is important to note that the corrosion front was found to advance slowly into the refractory after static and dynamic corrosion tests; regardless of whether the frit was in contact with the large mullite or andalusite grain, or with the grain boundary. This indicates that chemically, this type of refractory is not compatible with frit melts. Dissolution occurs mainly independent of the microstructure.

Alumina crucible was used to contain the molten frit bath that is the corrosive medium for refractory samples. During the corrosion test dissolution of Al will take place both from the refractory and from the crucible walls into the molten frit bath. The contribution of $\mathrm{Al}$ from the crucible will reduce the corrosive potential of the slag. But in this study no significant reduction in the corrosive capacity of the frit was observed due to partial dissolution of crucible as shown in Figs. 9 and 10 .

\section{Conclusions}

Corrosion testing between two types of refractories and a molten frit for glazes indicated the following conclusions: $\mathrm{E}$ type bricks were found to be more resistant to the corrosive frit melt than $\mathrm{T}$ type bricks in both static and dynamic corrosion tests when comparing the percent wear by cross sectional loss. This result was probably due to the proportion of sillimanite bond and impurities in the " $\mathrm{T}$ " microstructures that could be suspectible to dissolution during corrosion. Furthermore, E type brick based on a mullitic phase was more advantageous because it was the only stable high temperature compound in the binary $\mathrm{Al}_{2} \mathrm{O}_{3}-\mathrm{SiO}_{2}$ phase diagram. The temperature and exposure duration were found to be significant factors affecting corrosion. In the case of static corrosion tests, increasing temperature and immersion time led to more corrosion at the cross-sectional areas of corroded refractory specimens. Along the frit-refractory interface, needle-like mullite crystals, corundum crystals with different shapes, and white $\mathrm{ZnAl}_{2} \mathrm{O}_{4}$ spinel crystals were observed because of frit-refractory interactions at 1404 and $1504{ }^{\circ} \mathrm{C}$ during 4-24 h. Dynamic corrosion tests at 1418 and $1456{ }^{\circ} \mathrm{C}$ during $10-60 \mathrm{~min}$ of exposure concluded that higher temperature and immersion time resulted in more corrosion. Along the frit-refractory interface, the needle-like mullite, corundum and $\mathrm{ZnAl}_{2} \mathrm{O}_{4}$ crystals were observed as precipitation products.

\section{Acknowledgements}

The authors would like to thank the Scientific and Research Council of Turkey (TÜBITAK) for the financial support through project number 104M403. They also thank the staff of the Center for Materials Research, Izmir Institute of Technology for their helps in SEM and XRD analysis.

\section{References}

[1] A. Eppler Richard, R. Eppler Douglas, Glazes and Glass Coatings, The American Ceramic Society, Westerville, OH, 2000, pp. 29-80.

[2] G. Evans, Monitoring Refractory Wear, Glass Furnaces, The Refractories Engineer, November 2006, pp. 7-10.

[3] V.D. Tokarev, S.S. Igat'ev, O.N. Popov, Analysis of service of refractories in glass-melting tank furnaces, Glass and Ceramics 63 (5) (2006) 19-22.

[4] B.L. Krasnyi, V.P. Tarasovskii, A.L. Kuteinikova, Evaluation of corrosion resistance of refractory materials in furnaces for melting frit glazes, Glass and Ceramic 62 (9) (2005) 26-27.

[5] Akira Nishikawa, Section: 3 corrosion, in: Technology of Monolithic Refractories, vol. 1, Plibrico Japan Company Limited, Minato-ku, Tokyo, 1984, pp. 212-224.

[6] Annual Book of ASTM Standards, Section: 15 General Products, Chemical Specialites, and End Use Products, Refractories, Carbon and Graphite Products, Activated Carbon, vol. 15.01, 1992, pp. 167-172.

[7] W.E. Lee, W.M. Rainforth, Ceramic Microstructures, Property Control by Processing, published by Chapman \& Hall, London, UK, 1994, pp. $453-$ 506.

[8] J. Poirier, F. Qafssaoui, J.P. Ildefonse, P. Hubert, Influence of the liquid phase on the slag corrosion of andalusite based refractories, Refractories Applications Transactions 1 (1) (2004).

[9] S. Akkurt, H.D. Leigh, Corrosion of $\mathrm{MgO}-\mathrm{C}$ ladle refractories, American Ceramic Society Bulletin 82 (5) (2003) 32-40.

[10] M. Velez, R.E. Moore, J. Smith, Refractory Degradation in Glass Tank Melters. A Survey of Testing Methods, vol. 43, Ceramica, Brazil, 1997, pp. 283-284.

[11] S. Meyer-Rau, R. Telle, Testing strategies for corrosive interactions of ceramics with semi-solid and molten metals alloys, Journal of The European Ceramic Society 25 (2005) 1049-1055.

[12] S.M. Winder, A. Gupta, K.R. Selkregg, Investigation of liquid contact refractory corrosion under oxy-fuel glass melting atmosphere, Ceramic Engineering and Science Proceedings 19 (1) (1998) 53-73.

[13] A.R. Cooper, W.D. Kingery Jr., Dissolution in ceramic systems: molecular diffusion, natural convection studies of sapphire dissolution in calcium aluminum silicate, Journal of The American Ceramic Society 47 (1) (1963) 37-43.

[14] M. Kobayashi, N. Nishi, A. Miyamoto, Slag resistance tests for refractories, Taikabutsu Overseas 2 (1982) 5-13.

[15] H. Harris, W. Lautenberger, Strategy of Experimentation, El Dupont Short Course Notes, USA, 1976. 
[16] D.C. Montgomery, Design and Analysis of Experiments, 6th Edition, John Wiley \& Sons Inc., 2005, pp. 203-224.

[17] Z. Xiao, B.S. Mitchell, Mullite decomposition kinetics and melt stabilization in the temperature range $1900-2000{ }^{\circ} \mathrm{C}$, Journal of American Ceramic Society 83 (4) (2000) 761-767.
[18] Y. Iqbal, W.E. Lee, Influence of mixing on mullite formation in porcelain, Journal of European Ceramic Society 21 (2001) 2583-2586.

[19] C. Senoz, S. Akkurt, Corrosion of dense alumina and zirconia crucibles in frit melts, American Ceramic Society Bulletin 87 (8) (2008) 92019204. 